ISSN: 2162-3104 Print/ ISSN: 2166-3750 Online

Volume 10, Issue S3 (2020), pp. 161-179

(C) Journal of International Students

https://ojed.org/jis

\title{
The Emotional Geography of International Students in Online Bahasa Indonesia Learning during the COVID-19 Pandemic
}

\section{Geografi Emosi Mahasiswa Internasional dalam Belajar Bahasa Indonesia secara Daring pada Masa COVID-19}

\author{
Gatut Susanto
}

Universitas Negeri Malang, Indonesia

Suparmi

Universitas Islam Negeri Maulana Malik Ibrahim Malang, Indonesia

\author{
Endah Yulia Rahayu \\ Universitas Negeri Malang, Indonesia \\ Universitas PGRI Adi Buana Surabaya, Indonesia
}

\begin{abstract}
This article reports a case study that explores the emotional geography of 25 international students from 12 countries in learning bahasa Indonesia for foreigners virtually during the COVID-19 pandemic. Grounded in a qualitative case study design, the recruited participants were interviewed about their emotional experience of learning bahasa Indonesia online. Data were garnered from the interviews, classroom observations, and students' testimonials. They were analyzed with Hargreaves's (2001) emotional geography theory. Findings showed that online bahasa Indonesia learning affects the emotional geography of international students. The international students experienced such positive feelings as intimacy, safety, happiness, seriousness, and successfulness. However, they also experienced such negative feelings as confusion, anxiety, and shock situated in online bahasa Indonesia learning. This indicates that
\end{abstract}


international students should have positive feelings and maintain such feelings in order to succeed in online bahasa Indonesia learning.

ABSTRAK: Artikel ini melaporkan studi kasus yang mengeksplorasi geografi emosi 25 mahasiswa internasional dari 12 negara dalam belajar bahasa Indonesia bagi Penutur Asing secara daring pada masa COVID-19. Dalam penelitian studi kasus kualitatif ini, partisipan direkrut dan diwawancarai mengenai pengalaman geografi emosi mereka dalam belajar bahasa Indonesia secara daring. Data dikumpulkan dari observasi kelas, rekaman testimoni dan wawancara. Data tersebut selanjutnya dianalisis dengan teori geografi emosi Hargreaves (2001). Temuan penelitian menunjukkan bahwa pembelajaran bahasa Indonesia bagi Penutur Asing daring berpengaruh pada emosi mahasiswa internasional. Mahasiswa internasional mengalami perasaan positif, seperti keakraban, keamanan, kebahagiaan, keseriusan dan kesuksesan. Namun, mereka juga mengalami perasaan emosi negatif, seperti kebingungan, kecemasan dan keterkejutan dalam menjalani pembelajaran tersebut. Temuan penelitian tersebut mengindikasikan bahwa mahasiswa internasional seharusnya memiliki perasaan positif dan menjaga perasaan tersebut untuk keberhasilan dalam pembelajaran bahasa Indonesia bagi Penutur Asing secara daring.

Keywords: bahasa Indonesia for foreigners, COVID-19, emotional geography, international students, online learning [bahasa Indonesia bagi Penutur Asing, COVID19, geografi emosi, mahasiswa internasional, pembelajaran daring]

\section{PENDAHULUAN}

Wabah COVID-19 yang terjadi pada awal tahun 2020 telah mengubah perilaku kehidupan di masyarakat. Hal ini juga terjadi di dunia pendidikan. Kelas-kelas yang biasanya diselenggarakan secara tatap muka berubah secara tiba-tiba menjadi kelas daring. Perubahan pembelajaran tatap muka menjadi pembelajaran daring ini dirasakan oleh dosen dan mahasiswa. Situasi ini dilaporkan oleh Corbera, Anguelovski, Honey-Rosés dan Ruiz-Mallén (2020) bahwa COVID-19 telah memaksa akademisi bekerja di rumah. Hal ini juga terjadi pada pembelajaran bahasa Indonesia bagi Penutur Asing (BIPA). Mahasiswa internasional yang belajar BIPA tiba-tiba harus menghadapi pembelajaran secara daring. Pembelajaran yang biasanya dihadiri oleh dosen dan mahasiswa di suatu tempat yang sama, akibat pandemi COVID-19, telah memaksa mereka untuk melaksanakan pembelajaran BIPA secara daring di wilayah geografis yang berbeda. Pembelajaran BIPA secara daring ini menimbulkan geografi emosi beragam bagi para mahasiswa internasional. Dalam pembelajaran seperti ini, mahasiswa internasional tidak hanya bergulat dengan pengetahuan, daya kognitif dan ketrampilan, tetapi mereka juga bergulat dengan praktik-praktik emosi (Hargreaves, 2001). Berbagai praktik emosi manusia berhubungan dengan geografi emosi, yang mana hal tersebut berkaitan dengan geografi manusia dan geografi tempat.

Penelitian tentang geografi emosi telah dilakukan oleh peneliti terdahulu. Misalnya, Liu (2016) meneliti geografi emosi dosen bahasa Inggris sebagai bahasa kedua yang mempunyai latar belakang imigran dalam komunitas dosen 
profesional di Inggris. Hasil penelitian Liu menunjukkan bahwa dosen mengalami berbagai emosi baik positif maupun negatif dalam melaksanakan pembelajaran bahasa Inggris sebagai bahasa kedua. Untuk itu, dosen harus bisa menemukan strategi untuk mengelola geografi emosinya. Penelitian lain tentang geografi emosi dilakukan oleh Marvell dan Simm (2018) yang mengkaji geografi emosi mahasiswa yang sedang melakukan praktik kerja lapangan. Hasil penelitian tersebut mengungkapkan bahwa mahasiswa merasa sering diremehkan di tempat praktik kerja mereka. Situasi ini sangat memengaruhi geografi emosi mahasiswa, misalnya selalu merasa takut, cemas dan tidak aman. Penelitian yang relatif baru dilakukan oleh Sidhu dan Ishikawa (2020) yang mengeksplorasi geografi emosi mahasiswa internasional di Asia Timur. Dalam penelitian tersebut, Sidhu dan Ishikawa menemukan bahwa emosi mahasiswa digerakkan oleh pendidikan, kritik politik dan kepedulian.

Berdasarkan penelitian-penelitian di atas, diketahui bahwa penelitian tentang geografi emosi mahasiswa internasional yang belajar BIPA belum dilakukan. Oleh karena itu, penelitian tentang pengalaman emosi mahasiswa internasional yang belajar BIPA penting dilakukan, terutama pada pembelajaran BIPA secara daring pada masa COVID-19. Berdasarkan fenomena tersebut, penelitian ini bertujuan untuk mengkaji pengalaman emosi mahasiswa internasional dalam belajar BIPA secara daring pada masa COVID-19. Penelitian ini akan memberikan manfaat teoretis pada pemahaman lintas budaya dan manfaat praktis bagi para dosen BIPA serta mahasiswa internasional. Dosen BIPA dapat memperoleh manfaat pengetahuan tentang geografi emosi mahasiswa internasional, sehingga dalam melaksanakan pembelajaran, mereka dapat memperlakukan mahasiswa internasional dengan lebih bijaksana sesuai dengan situasi emosi mereka. Mahasiswa internasional dapat memanfaatkan hasil penelitian untuk mencari tahu perasaan apa saja yang penting dimiliki dan dijaga dalam menjalani pembelajaran bahasa asing secara daring.

\section{KERANGKA TEORETIS DAN KAJIAN KONSEPTUAL}

Bagian ini membahas geografi emosi sebagai kerangka teoretis dan konsepkonsep terkait, seperti mahasiswa internasional dan BIPA serta pembelajaran daring pada masa COVID-19. Kajian ini dibutuhkan sebagai pijakan teoretis dan konseptual untuk memaknai geografi emosi mahasiswa internasional dalam belajar BIPA secara daring pada masa COVID-19.

\section{Geografi Emosi}

Emosi adalah situasi psikologis manusia yang menggambarkan perasaan senang, sedih, marah, benci, takut dan perasaan sejenisnya (Barbalet, 1999). Situasi psikologis tersebut disebabkan oleh faktor internal dan eksternal manusia. Dalam ilmu sosial humaniora, kajian yang membahas emosi manusia disebut geografi emosi. Hubungan antara geografi manusia dan emosi manusia dijelaskan oleh Bondi (2016), geografi emosi berada pada tubuh manusia dan 
tempat manusia berada. Emosi manusia disebabkan oleh interaksi manusia dengan manusia lainnya dan interaksi manusia dengan lingkungannya. Geografi emosi menggambarkan perasaan manusia di mana manusia hidup dan memerankan hidup di tempat-tempat tertentu (Anderson \& Smith, 2001). Lebih lanjut dijelaskan oleh Hargreaves $(2001,2005)$ bahwa emosi manusia berkaitan dengan interaksi manusia dengan manusia lain secara universal. Jadi, geografi emosi ditentukan oleh interaksi manusia secara luas, tidak hanya terbatas pada interaksi fisik secara sosial dan budaya, tetapi juga berkaitan dengan situasi psikologis dan lingkungan manusia berada.

Hargreaves (2000) menekankan bahwa geografi emosi mengkaji pengalaman manusia yang menyebabkan jauh dan/atau dekatnya sebuah hubungan seseorang dengan pihak lain berdasarkan emosi yang dialaminya dalam waktu tertentu. Selanjutnya, Hargreaves (2001) membagi geografi emosi menjadi lima dimensi, yaitu geografi fisik (personal), geografi moral, geografi sosiokultural, geografi profesional dan geografi politik. Geografi fisik (personal) mengacu pada hubungan dekat dan/atau jauh seseorang yang diciptakan oleh ruang dan waktu. Geografi moral berkaitan dengan kedekatan seseorang dalam berinteraksi dengan orang lain yang disebabkan oleh tujuan yang sama dan tatanan norma yang berlaku di masyarakat. Geografi sosiokultural mengacu pada hubungan kedekatan seseorang yang tercipta oleh perbedaan jenis kelamin, ras, suku, bahasa dan budaya. Geografi ini terkait dengan pengalaman seseorang ketika berinteraksi dengan norma sosial dan norma budaya yang berlaku di suatu masyarakat. Geografi profesional berkaitan dengan kedekatan hubungan seseorang dengan orang lain berdasarkan pemahaman mereka terhadap norma profesional dan praktik profesional. Geografi politik mengacu pada hubungan kedekatan seseorang dengan orang lain yang disebabkan oleh faktor-faktor kekuasaan dan status sosial yang melekat pada setiap orang. Berdasarkan penjelasan di atas dapat dikatakan bahwa geografi emosi mengkaji pengalaman perasaan seseorang dalam berinteraksi dengan orang lain di lingkungannya.

\section{Mahasiswa Internasional dan Bahasa Indonesia bagi Penutur Asing (BIPA)}

Mahasiswa internasional atau mahasiswa asing adalah mahasiswa yang berada di suatu negara yang memiliki status sebagai warga negara asing. Pengertian tersebut mengindikasikan bahwa para mahasiswa internasional meninggalkan negaranya untuk pindah sementara waktu di negara lain guna belajar. Mahasiswa yang meninggalkan negara asalnya dan pindah ke negara lain untuk tujuan studi diklasifikasikan sebagai mahasiswa internasional (OECD, 2012). Di negara tujuan belajar, mahasiswa internasional ini selain belajar bidang keilmuan juga belajar hidup bersama dengan orang dan budaya yang baru (Sidhu \& Ishikawa, 2020). Ketika berinteraksi dengan orang dan budaya yang baru, mahasiswa internasional akan mendapatkan pengalaman yang baru pula. Salah satu pengalaman yang didapat mahasiswa internasional adalah pengalaman penyesuaian budaya. Dalam proses ini, emosi dan ketentraman 
mereka akan terganggu. Bentuk gangguan emosi dan ketentraman ini menyebabkan munculnya beragam masalah sosial, budaya, keamanan, kesejahteraan dan kesehatan (Forbes-Mewett \& Sawyer, 2016).

Dalam konteks BIPA di Indonesia, mahasiswa internasional dan BIPA memiliki kaitan yang sangat erat. Kaitan erat itu tampak pada tidak terhindarkannya pembicaraan BIPA dari pembicaraan tentang mahasiswa internasional. Ada beberapa perbedaan penamaan BIPA, misalnya, bahasa Indonesia bagi penutur asing (Indonesian for foreigners), bahasa Indonesia sebagai bahasa internasional (Indonesian as an international language) dan bahasa Indonesia sebagai bahasa asing (Indonesian as a foreign language). Namun, pada hakikatnya, semua penamaan BIPA tersebut merujuk kepada orang asing yang belajar bahasa Indonesia. Dalam konteks pembelajaran, pembelajaran BIPA dan pembelajaran bahasa Indonesia untuk orang Indonesia memiliki karakteristik yang berbeda. Perbedaan-perbedaan karakteristik tersebut tampak pada semua komponen pembelajarannya, baik pada komponen kurikulum, dosen, mahasiswa, bahan ajar, proses belajar mengajar maupun pada aspek evaluasinya. Dengan kata lain, secara keseluruhan, program BIPA baik secara kurikulum, instruksional dan asesmen didesain untuk para penutur asing yang ingin mempelajari bahasa Indonesia dan budaya Indonesia.

Ditinjau dari aspek kurikulum, pembelajaran bahasa Indonesia untuk orang Indonesia dan pembelajaran BIPA juga berbeda. Kurikulum bahasa Indonesia acuannya adalah kurikulum nasional yang ditetapkan oleh Kementerian Pendidikan dan Kebudayaan serta diberlakukan secara nasional. Sementara itu, kurikulum BIPA ditetapkan oleh masing-masing lembaga penyelenggara BIPA. Di Indonesia, tidak ada kurikulum BIPA yang ditetapkan dan diberlakukan secara nasional. Oleh karena itu, setiap lembaga penyelenggara BIPA diberi otonomi untuk mengembangkan kurikulum BIPA. Pengembangan kurikulum BIPA di setiap lembaga BIPA disesuaikan dengan karakteristik program BIPA yang dikelola oleh masing-masing lembaga penyelenggara BIPA tersebut. Namun demikian, secara umum, lembaga penyelenggara BIPA di Indonesia dalam mengembangkan kurikulumnya menggunakan acuan kurikulum yang berdasarkan Common European Framework of Reference (CEFR), American Council on the Teaching of Foreign Languages (ACTFL) dan Standar Kompetensi Lulusan (SKL). Ketiga kurikulum ini memuat keempat aspek keterampilan berbahasa menyimak, berbicara, membaca dan menulis.

Berdasarkan acuan kurikulum CEFR (Council of Europe, 2001; Little, 2006), kurikulum BIPA dibagi menjadi enam tingkatan, yaitu kurikulum BIPA untuk tingkat Pemula Bawah (A1), Pemula Atas (A2), Madya Bawah (B1), Madya Atas (B2), Unggul (C1) dan Sangat Unggul (C2). Menurut acuan ACTFL (2012), pemeringkatan kemahiran berbahasa asing dibagi menjadi 11 tingkatan sebagai berikut: (1) Distinguished, (2) Superior, (3) Advance High, (4) Advance Mid, (5) Advance Low, (6) Intermediate High, (7) Intermediate Mid, (8) Intermediate Low, (9) Novice High, (10) Novice Mid dan (11) Novice Low. Acuan ACTFL ini dalam kurikulum BIPA biasanya diadopsi menjadi BIPA tingkat Dasar, BIPA tingkat Menengah dan BIPA tingkat Lanjut. BIPA 
tingkat Dasar dibagi menjadi BIPA Dasar I yang setara dengan Novice Low dan BIPA Dasar II yang setara dengan Novice High. Dalam kurikulum, tingkat Madya dibagi menjadi Madya 1 yang setara dengan Intermediate Low dan Madya II yang setara dengan Intermediate High. Sedangkan, BIPA tingkat Lanjut dibagi menjadi BIPA tingkat Lanjut I yang setara dengan Advance Low dan BIPA tingkat Lanjut II yang setara dengan Advance High. Acuan kurikulum internasional CEFR dan ACTFL diadopsi dalam pembelajaran BIPA untuk menentukan peringkat kemahiran berbahasa Indonesia orang asing. Acuan kurikulum ini diadaptasi untuk merancang tujuan pembelajaran, bahan ajar dan penentuan kriteria hasil belajar BIPA. Diadaptasinya kedua kurikulum ini disebabkan oleh belum tersedianya acuan kurikulum BIPA di Indonesia yang menjelaskan kebutuhan pemeringkatan pembelajaran BIPA.

Acuan kurikulum BIPA yang ketiga adalah Standar Kompetensi Lulusan (SKL). Acuan kurikulum SKL BIPA didasarkan pada Peraturan Menteri Pendidikan dan Kebudayaan Nomor 27 Tahun 2017 tentang Standar Kompetensi Lulusan (SKL) BIPA. Menurut SKL, kurikulum BIPA dibagi menjadi tujuh tingkat kemahiran, yaitu BIPA I (kemahiran terbatas), BIPA 2 (kemahiran marginal), BIPA 3 (kemahiran semenjana), BIPA 4 (kemahiran madya), BIPA 5 (kemahiran unggul), BIPA 6 (kemahiran sangat unggul) dan BIPA 7 (kemahiran istimewa). Pemeringkatan kemahiran berbahasa Indonesia mahasiswa internasional ini disesuaikan dengan pemeringkatan Uji Kemahiran Berbahasa Indonesia (UKBI) yang ditetapkan oleh Badan Bahasa, Kementerian Pendidikan dan Kebudayaan yang berkantor di Jakarta.

\section{Pembelajaran Daring Masa COVID-19}

Pembelajaran daring adalah pembelajaran dalam jaringan. Pembelajaran ini menekankan penggunaan teknologi informasi dan jaringan yang berupa internet (Choudhury \& Pattnaik, 2020). Wabah COVID-19 telah mengubah pelaksanaan pembelajaran dari tatap muka menjadi pertemuan secara daring (Moorhouse, 2020; Morgan, 2020; Murphy, 2020). Studi tentang pembelajaran daring telah banyak dikaji dari berbagai aspek, seperti strategi pembelajaran daring, persepsi mahasiswa atau dosen terhadap pembelajaran daring dan tantangan dalam pembelajaran daring. Tinjauan studi oleh Moorhouse (2020) menggambarkan strategi yang digunakan oleh dosen dalam pengajaran daring, di antaranya dengan menggabungkan mode sinkron dan asinkron. Pengajaran sinkron dengan menggunakan konferensi video selama pembelajaran berlangsung. Sedangkan dalam pengajaran asinkron, dosen membagikan materi melalui web, email atau pesan yang dikirimkan ke forum komunitas.

Penelitian lain oleh Manegre dan Sabiri (2020) mengkaji persepsi dosen dalam pembelajaran bahasa secara daring pada masa COVID-19. Studi ini melaporkan bahwa pada umumnya, para dosen menyatakan bahwa pembelajaran daring sama efektifnya dengan pembelajaran tatap muka. Selain itu, dosen menegaskan bahwa pembelajaran daring bisa menjadi pembelajaran alternatif, yang bisa menggantikan kelas tradisional untuk mata kuliah tertentu. 
Tinjauan studi mengenai aspek tantangan pembelajaran daring dilakukan oleh Morgan (2020) yang meneliti tantangan yang dihadapi oleh dosen dan mahasiswa dalam pembelajaran pada masa COVID-19. Di beberapa kampus, ditemukan adanya dosen yang tidak berpengalaman dalam pembelajaran daring, dan tidak semua mahasiswa mempunyai akses internet di rumah. Hal ini menyebabkan pembelajaran daring menjadi kurang efektif. Dalam menghadapi tantangan ini, dosen perlu meningkatkan kemampuan menggunakan teknologi untuk mengajar secara daring. Hal ini sesuai dengan temuan riset oleh Corbera, Anguelovski, Honey-Rosés dan Ruiz-Mallén (2020) bahwa para akademisi harus mampu meningkatkan pengajaran daring dengan menguasai teknologi serta moda virtual yang bisa digunakan dalam pembelajaran daring.

Berbagai pilihan moda (platform) pembelajaran daring yang digunakan antara lain, Zoom, Google Meet, Google Classroom, Skype, WebEx, Facebook Group, Edmodo, WhatsApp dan Line. Beberapa ahli telah meneliti penggunaan beberapa platform tersebut dalam pembelajaran daring pada masa COVID-19. Chick, Clifton, Peace, Propper, Hale, Alseidi dan Vreeland (2020) melakukan investigasi tentang penggunaan Zoom, Skype, WebEx dan Facebook group dalam pembelajaran daring yang mana ditemukan bahwa moda-moda virtual tersebut merupakan salah satu inovasi dan solusi pembelajaran pada masa COVID-19 dan terbukti efektif digunakan dalam pembelajaran daring. Zoom dan Skype biasa digunakan untuk menyampaikan materi pembelajaran, sedangkan Facebook Group, Edmodo, WhatsApp dan Line digunakan untuk memberikan bahan ajar, tugas, umpan balik serta evaluasi.

\section{METODE PENELITIAN}

\section{Partisipan}

Partisipan penelitian ini adalah 25 mahasiswa internasional dari 12 negara, yaitu Amerika, Australia, Brazil, Cina, India, Jepang, Korea Selatan, Mesir, Pakistan, Panama, Rusia dan Thailand. Partisipan terdiri atas tujuh pria dan 18 wanita, dengan usia termuda 16 tahun dan tertua 65 tahun. Pekerjaan peserta program adalah siswa SMA, dosen, diplomat, mahasiswa, peneliti, konsultan, wiraswasta dan pebisnis. Deskripsi partisipan penelitian digambarkan dalam Tabel 1. Nama mahasiswa tidak dituliskan dengan alasan untuk menjaga privasi mereka.

\section{Tabel 1. Partisipan Penelitian}

\begin{tabular}{clllll}
\hline Kelas & \multicolumn{1}{c}{ Nama } & Gender & Usia & Asal Negara & \multicolumn{1}{c}{ Pekerjaan } \\
\hline Kelas Dasar I & Mahasiswa 1 & Pria & 16 & Amerika & Siswa SMA \\
& Mahasiswa 2 & Wanita & 52 & Brazil & Dosen \\
& Mahasiswa 3 & Wanita & 45 & Rusia & Diplomat \\
& Mahasiswa 4 & Wanita & 22 & Australia & Mahasiswa \\
& Mahasiswa 5 & Pria & 20 & Mesir & Mahasiswa \\
Kelas Dasar II & Mahasiswa 1 & Wanita & 21 & Amerika & Mahasiswa \\
& Mahasiswa 2 & Wanita & 56 & Amerika & Peneliti \\
& Mahasiswa 3 & Wanita & 29 & India & Mahasiswa
\end{tabular}




\begin{tabular}{clllll} 
& Mahasiswa 4 & Wanita & 23 & Pakistan & Mahasiswa \\
\multirow{5}{*}{ Kelas Madya I } & Mahasiswa 5 & Wanita & 20 & Amerika & Mahasiswa \\
& Mahasiswa 1 & Wanita & 22 & Jepang & Mahasiswa \\
& Mahasiswa 2 & Wanita & 25 & Cina & Mahasiswa \\
& Mahasiswa 3 & Wanita & 41 & Korea & Konsultan \\
& Mahasiswa 4 & Pria & 24 & Mesir & Mahasiswa \\
& Mahasiswa 5 & Pria & 65 & Amerika & Wiraswasta \\
Kelas Madya II & Mahasiswa 1 & Wanita & 19 & Panama & Mahasiswa \\
& Mahasiswa 2 & Wanita & 47 & Amerika & Diplomat \\
& Mahasiswa 3 & Pria & 22 & Thailand & Mahasiswa \\
& Mahasiswa 4 & Wanita & 25 & India & Mahasiswa \\
& Mahasiswa 5 & Pria & 20 & Rusia & Mahasiswa \\
& Mahasiswa 1 & Pria & 20 & Pakistan & Mahasiswa \\
& Mahasiswa 2 & Wanita & 20 & Amerika & Mahasiswa \\
& Mahasiswa 3 & Wanita & 34 & Korea & Pebinis \\
& Mahasiswa 4 & Wanita & 22 & Amerika & Mahasiswa \\
& Mahasiswa 5 & Wanita & 28 & Cina & Mahasiswa \\
\hline
\end{tabular}

\section{Pengumpulan Data}

Data penelitian geografi emosi partisipan dikumpulkan dengan cara melakukan wawancara, observasi kelas daring, melihat rekaman video testimoni dan menyebarkan angket penelitian sistem esai terbuka. Peneliti melakukan wawancara mendalam kepada partisipan melalui aplikasi Zoom. Wawancara dilakukan sebanyak tiga kali, yaitu pada minggu pertama, pertengahan program dan minggu terakhir menjelang program berakhir. Partisipan yang diwawancarai dikelompokkan dalam tiga kategori, yaitu partisipan yang aktif dan ekspresif, partisipan yang tidak aktif dan tidak ekspresif serta partisipan yang biasa-biasa saja. Dalam melakukan wawancara, peneliti menggunakan parameter penilaian bahasa yang meliputi: ketertarikan (inclination) dan ketidaktertarikan (disinclination), kepuasan (satisfaction) dan ketidakpuasan (dissatisfaction), kenyamanan (security) dan ketidaknyamanan (insecurity) serta kebahagiaan (happiness) dan ketidakbahagiaan (unhappiness) yang dialami oleh partisipan (Martin \& White, 2005). Pertanyaan yang diajukan dalam wawancara tidak secara langsung terkait dengan geografi emosi mereka, tetapi lebih umum untuk mengungkap perasaan partisipan dalam mengikuti kelas daring. Pertanyaan-pertanyaan tersebut, misalnya: bagaimana perasaan Anda mengikuti kelas virtual ini? Bagaimana kesan Anda terhadap dosen, teman dan materi yang diberikan? Jawaban mahasiswa atas pertanyaan-pertanyaan tersebut, secara tidak langsung akan mengungkap geografi emosi mereka.

Selain melakukan wawancara, peneliti dengan menggunakan parameter yang sama juga melakukan observasi kelas secara daring melalui aplikasi Zoom. Kemudian peneliti menuliskan data geografi emosi mahasiswa dalam bentuk paragraf pendek. Kelas yang diobservasi berjumlah lima kelas dengan tingkat kemampuan yang berbeda. Kelas-kelas yang dipilih adalah: Kelas Dasar I (Novice Low), Kelas Dasar II (Novice High), Kelas Madya I (Intermediate Low), Kelas Madya II (Intermediate High) dan Kelas Lanjut I (Advanced Low). Berikutnya, parameter tersebut juga digunakan peneliti ketika melihat rekaman 
video testimoni. Data video ini berguna untuk menemukan kata-kata sifat, ekspresi luapan perasaan dan mencari kalimat-kalimat partisipan yang menggambarkan perasaan-perasaan positif dan negatif mereka selama mengikuti pembelajaran BIPA secara daring (Juni-Juli 2020). Dari dua informasi lisan tersebut, peneliti membuat catatan tentang pengalaman geografi emosi mahasiswa internasional berupa teks dalam bentuk paragraf-paragraf pendek.

Selanjutnya, peneliti mengumpulkan data geografi emosi partisipan dengan cara menyebarkan angket penelitian secara elektronik yang dikemas dalam bentuk Google Form. Angket penelitian berisi tentang identitas partisipan yang mencakup nama, asal negara, jenis kelamin, umur dan pekerjaan. Selain itu, angket penelitian juga berisi penilaian partisipan terhadap dosen, partisipan lain, materi yang digunakan, proses belajar mengajar dan pengalaman partisipan selama mengikuti pembelajaran BIPA daring. Jawaban partisipan atas angket tersebut selanjutnya disalin dan ditulis menjadi teks.

\section{Analisis Data}

Teori geografi emosi Hargreaves (2001) digunakan untuk menganalisis data penelitian. Adapun prosedur analisis data dilakukan dengan cara sebagai berikut.

1. Data berupa teks paragraf pendek dikumpulkan dari hasil transkripsi wawancara, catatan observasi kelas, transkripsi video dan tulisan jawaban angket. Selanjutnya, data tersebut dibaca secara berulang dan cermat untuk memastikan bahwa data tersebut mengandung indikator geografi emosi, yaitu geografi fisik, geografi moral, geografi sosiokultural, geografi profesional dan geografi politik.

2. Data berupa teks yang mengandung indikator geografi emosi tersebut, selanjutnya dikodekan menjadi data wawancara (DW), data observasi (DO), data video (DV) dan data angket penelitian (DA).

3. Kumpulan data yang sudah dikodekan, selanjutnya diklasifikasikan menjadi lima dimensi, yaitu emosi fisik (EF), emosi moral (EM), emosi sosiokultural (ES), emosi profesional (EP) dan emosi politik (ET).

4. Dari proses kodifikasi dan klasifikasi data, diperoleh data hasil wawancara dengan kode data DWEF (data wawancara emosi fisik), DWEM (data wawancara emosi moral), DWES (data wawancara emosi sosiokultural), DWEP (data wawancara emosi profesional) dan DWET (data wawancara emosi politik).

5. Data observasi diberi kode data DOEF (data observasi emosi fisik), DOEM (data observasi emosi moral), DOES (data observasi emosi sosiokultural), DOEP (data observasi emosi profesional) dan DOET (data observasi emosi politik).

6. Data dari video diberi kode data DVEF (data video emosi fisik), DVEM (data video emosi moral), DVES (data video emosi 
sosiokultural), DVEP (data video emosi profesional) dan DVET (data video emosi politik).

7. Data dari angket diberi kode data DAEF (data angket emosi fisik), DAEM (data angket emosi moral), DAES (data angket emosi sosiokultural), DAEP (data angket emosi profesional) dan DAET (data angket emosi politik).

8. Data yang sudah diklasifikasikan, selanjutnya diseleksi dan dianalisis dengan menggunakan parameter bahasa dalam ketertarikan (inclination) dan ketidaktertarikan (disinclination), kepuasan (satisfaction) dan ketidakpuasan (dissatisfaction), kenyamanan (security) dan ketidaknyamanan (insecurity) serta kebahagiaan (happiness) dan ketidakbahagiaan (unhappiness). Dalam tahapan ini, peneliti menandai dengan menebalkan kata, frasa dan kalimat yang menunjukkan parameter tersebut.

9. Peneliti menafsirkan bagian data yang sudah ditandai untuk menemukan makna geografi emosi (GE) di balik kata, frasa dan kalimat tersebut. Emosi-emosi ketertarikan, kepuasan, kenyamanan dan kebahagiaan ditafsirkan sebagai perasaan positif. Akan tetapi, emosiemosi ketidaktertarikan, ketidakpuasan, ketidaknyamanan dan ketidakbahagiaan ditafsirkan sebagai emosi negatif. Prosedur analisis data di atas mengadaptasi langkah-langkah menganalisis hasil wawancara oleh Widodo (2014).

Alur pengumpulan dan analisis data dapat digambarkan pada Bagan 1 berikut.

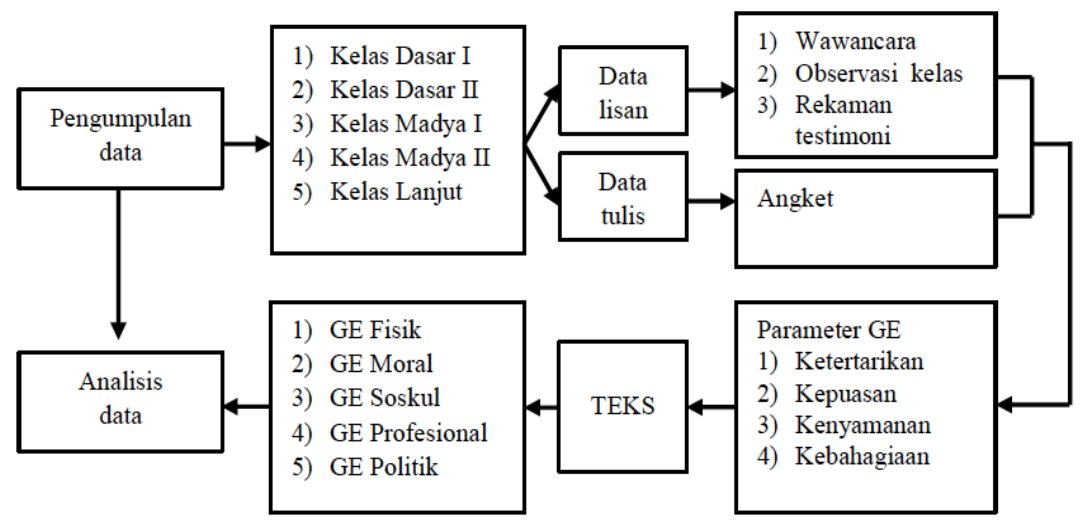

Bagan 1. Alur Pengumpulan dan Analisis Data

\section{TEMUAN DAN PEMBAHASAN}

Dalam temuan dan pembahasan geografi emosi mahasiswa internasional ini dibahas lima hal, yaitu geografi emosi fisik, geografi emosi moral, geografi emosi sosiokultural, geografi emosi profesional dan geografi emosi politik. 


\section{Geografi Emosi Fisik/Personal: "Aku cinta guru orang Indonesia”}

Geografi emosi fisik mengacu pada hubungan kedekatan seseorang yang disebabkan oleh ruang dan waktu (Hargreaves, 2001). Pembelajaran BIPA yang dilaksanakan secara daring pada masa COVID-19 telah menciptakan ruang dan waktu bagi mahasiswa internasional. Ruang dan waktu telah menimbulkan berbagai pengalaman emosi mahasiswa internasional. Perasaan partisipan yang menggambarkan geografi emosi fisik terdapat pada data berikut.

I am very happy (kebahagiaan) and thankful (kepuasan) joining this class (tempat) because I meet new friends from different countries (tempat). As an Indian, now I have friends from United States of America, Thailand, Panama, and Russia (tempat). They are nice and very helpful (kepuasan). Mostly, aku cinta (kebahagiaan dan kepuasan) guru orang Indonesia. Mereka sangat baik dan professional. (DAEF, 25 Juli 2020)

I don't like (ketidakpuasan)...he is talkative (ketidakpuasan)! He often interrupted (ketidaknyamanan) me when I am still thinking. I feel disrespectful (ketidakbahagiaan dan ketidaknyamanan) and that made me very uncomfortable (ketidaknyamanan) in class (tempat). Luckily (kepuasan), my teacher always helps the situation. (DWEF, Zoom, 16 Juli 2020)

Data di atas menunjukkan adanya emosi positif, yakni kebahagiaan, kepuasan dan kenyamanan. Mahasiswa memiliki perasaan tersebut karena mereka dapat mengenal teman baru yang berasal dari negara lain. Perasaanperasaan positif ini juga disebabkan oleh tempat, yaitu negara. Walaupun jarak fisik memisahkan mereka, tetapi kelas daring telah mempertemukan para partisipan sebagai teman baru. Mahasiswa juga senang bertemu dengan dosen bahasa Indonesia yang merupakan orang Indonesia asli. Mahasiswa tidak hanya mengalami perasaan positif, tetapi mereka juga mengalami perasaan negatif berupa ketidakpuasan, ketidakbahagiaan dan ketidaknyamanan. Perasaan negatif tersebut tampak pada perasaan tidak suka, cerewet dan tidak dihormati. Sebagai orang Amerika, India, Panama, Rusia dan Thailand, mereka merasa sebagai orang yang berbeda. Perbedaan tempat asal itu menentukan geografi emosi mahasiswa internasional karena tempat asal menentukan karakter mahasiswa. Perasaan yang dialami oleh mahasiswa internasional tersebut menunjukkan bahwa faktor internal berpengaruh terhadap tumbuhnya perasaan positif dan negatif. Temuan ini menegaskan penelitian Ramirez (1995), bahwa latar belakang individu merupakan salah satu faktor yang berpengaruh terhadap perasaan.

\section{Geografi Emosi Moral: "Mereka adalah teman saya sekarang"}

Geografi emosi moral berkaitan dengan kedekatan seseorang dalam berinteraksi dengan orang lain yang disebabkan oleh tujuan yang sama dan tatanan norma 
yang berlaku di masyarakat (Hargreaves, 2001). Mahasiswa internasional yang belajar bahasa Indonesia secara daring memiliki tujuan yang sama, yaitu berlatih menggunakan bahasa Indonesia. Interaksi mahasiswa dengan mahasiswa lain dan interaksi mahasiswa dengan pengajar memunculkan berbagai perasaan. Hal ini terungkap pada data berikut.

\begin{abstract}
Saya (orang) sangat senang (kepuasan) belajar bahasa dan budaya Indonesia di sini. Orang-orang di kelas (orang lain) adalah teman-teman saya (orang lain) sekerang (kepuasan). Saya harus bertemu guru saya (orang lain) di Indonesia, karena beliau (hormat-inclination) sudah teman saya (pengakuan-inclination). Karena para guru (orang) menjelaskan dengan mudah (kepuasan) dan mengomunikasikan informasi dengan cara yang sederhana (kepuasan) dan mereka (orang lain) adalah kepribadian yang disukai bagi kami (kebahagiaan), kami merasa bahwa mereka adalah saudara perempuan kami dan bukan guru (orang lain) kami. (DVEM, 24 Juli 2020)
\end{abstract}

Mbak (orang) ... and Mas (orang)... were patient (keyamanan), personable (kedekatan/ketertarikan), and dedicated (pujian-inclination) to assisting novice students (orang) with understanding bahasa Indonesia with as little English as possible and making sure we (orang) truly comprehended the word/grammar/etc. (DWEM, 12 Juni 2020)

Data-data di atas menunjukkan bahwa mahasiswa memiliki perasaan positif, yaitu ketertarikan, kepuasan, kebahagiaan dan kenyamanan. Tidak tergambar emosi negatif dari data yang dinarasikan oleh partisipan. Kata dan frasa seperti: sangat senang, sudah teman saya, mereka adalah saudara bukan guru (yang dimaksud adalah dosen), Mas dan Mbak menunjukkan adanya keakraban mahasiswa dan dosen. Praktik geografi emosi moral juga tercermin pada penggunaan kata beliau sebagai kata ganti untuk dosen sebagai bentuk penghormatan. Hubungan sesama mahasiswa dan antara mahasiswa dengan dosen di kelas telah menciptakan rasa baik dan nyaman. Hubungan mahasiswa dengan mahasiswa lain dan hubungan mahasiswa dengan dosen yang harmonis, bahkan akrab secara personal dimaksudkan untuk mencapai keberhasilan tujuan pembelajaran. Hubungan dekat di antara mereka tersebut oleh Hargreaves (2001; 2005) diklasifikasikan sebagai geografi emosi moral.

\title{
Geografi Emosi Sosiokultural: "Sebagai yang termuda di kelas, saya nyaman saja"
}

Geografi emosi sosiokultural mengacu pada hubungan kedekatan seseorang yang tercipta oleh perbedaan jenis kelamin, umur, pekerjaan, bahasa dan budaya (Hargreaves, 2001). Mahasiswa internasional yang belajar bahasa Indonesia daring memiliki faktor perbedaan individu. Mereka berbeda jenis kelamin, umur, pekerjaan dan negara asal yang memiliki perbedaan bahasa dan budaya. Interaksi orang-orang yang berbeda latar belakang tersebut menimbulkan berbagai perasaan, seperti terungkap pada data berikut. 
I love (ketertarikan) the program. As the youngest (umur) person in the class, I feel bagus (kenyamanan) in the class. I get support another student who is much older (umur) than me as well as from my lovely (ketertarikan) teachers (pekerjaan). I was worried (ketidaknyamanan) a lot in the beginning when I saw my classmate. I never studied before and I realized I am the only high school students in the class (tingkat pendidikan). (DWES, 26 Juni 2020)

I was shocked (ketidaknyamanan) when I knew that I am the only (ketidaknyamanan) Panamas student (asal negara) in the class. But later on, I feel so happy (kepuasan) with my class. I feel lucky (kebahagiaan) to have new friends from America, Russia, India and Thailand (asal negara). (DAES, 20 Juli 2020)

Perbedaan latar belakang mahasiswa internasional yang berupa perbedaan jenis kelamin, umur, jenjang pendidikan, pekerjaan dan asal negara menyebabkan terbentuknya struktur sosial di kelas. Struktur sosial tersebut menimbulkan beragam emosi positif seperti tampak pada penggunaan kata cinta, bagus, sangat senang dan merasa beruntung. Struktur sosial kelas berupa perbedaan umur, asal negara, pekerjaan dan jenjang pendidikan yang di awal menimbulkan perasaan negatif, akan tetapi, akhirnya berubah menjadi cair dan penuh perasaan positif sampai di akhir program. Hal ini terjadi karena selama berinteraksi, mahasiswa melakukan penyesuaian diri dengan mahasiswa lain. Hasil ini menguatkan temuan penelitian Geoghegan (2013) yang menyatakan bahwa emosi adalah inti cara orang mengalami dunia dan emosi membantu seseorang belajar. Kepuasan mahasiswa internasional yang multikultur dalam melakukan pembelajaran daring juga pernah dilaporkan oleh Volet dan Wosnitza (2004) bahwa peserta merasa puas karena mahasiswa dapat berinteraksi dengan teman sebaya dari negara lain. Perasaan positif seperti ini juga dilaporkan oleh Hill, Healey, West dan Déry (2019) bahwa teman sebaya adalah mitra belajar yang dapat memberikan dorongan terhadap kepuasan belajar mahasiswa.

\section{Geografi Emosi Profesional: "Guru-gurunya berdedikasi, bersemangat, baik hati dan berpengetahuan luas"}

Geografi emosi profesional mengacu pada hubungan kedekatan seseorang dengan pihak lain yang terbentuk oleh pemahaman manusia terhadap norma profesional dan praktik profesional (Hargreaves, 2001). Data geografi emosi profesional mahasiswa internasional yang mengikuti pembelajaran BIPA daring pada masa COVID-19 sebagai berikut.

This is a fantastic (ketertarikan) program with outstanding (pengakuan ketertarikan) organization and teaching. The teaching I experienced at UM is unparalleled (kepuasan) to any teaching I have ever had in the States. The teachers are dedicated, enthusiastic, kind, and knowledgeable (kepuasan dan kebahagiaan atas praktik profesional). (DAEP, 25 Juli 2020) 
Mas ... dan Mas ... merupakan guru-guru luar biasa (kepuasan praktik profesional). Setiap hari di kelas, kita membahas topik yang menarik dan worksheet yang diberikan kepada mahasiswa di kelas selalu jelas (kepuasan) dan secara logis (kepuasan) dengan kosa kata target dan tata bahasa. Menurut opini saya, materi di kelas selalu menjelaskan secara bagus (kepuasan). Selain itu, saya sangat menyukai (kepuasan) bertemu teman baru melalui percakapannya. (Mahasiswa 1, 2, 3, 4 dan 5, DVEP, 24 Juli 2020)

Data-data di atas menggambarkan bahwa mahasiswa internasional hanya mengalami perasaan positif. Mereka merasa puas karena dosen yang mengajar berdedikasi, bersemangat, baik hati dan berpengetahuan luas. Ungkapan geografi emosi tersebut menunjukkan bahwa penyelenggara program dan para dosen telah memahami norma profesional dan menerapkannya dalam praktik profesional mengajarkan BIPA. Hal ini mengindikasikan bahwa dosen dan mahasiswa berinteraksi secara profesional. Seperti dilaporkan oleh Liu (2016), interaksi profesional dosen dan mahasiswa menyebabkan tumbuhnya perasaan positif di antara mereka.

\section{Geografi Emosi Politik: "Saya merasa senang karena saya diberi keadilan"}

Geografi emosi politik mengacu pada hubungan dekat seseorang yang disebabkan oleh faktor-faktor kekuasaan dan status sosial (Hargreaves, 2001). Berikut disajikan data-data yang menunjukkan geografi emosi politik mahasiswa internasional.

I would like to know the Indonesian language for better understanding of Indonesian culture and its social life. Indonesia is a growing country which has good diplomatic relationships with Russia (ketertarikan). Knowing the language can be an opportunity for my future career (ketertarikan). Moreover, it could help me to share my experience and tell Indonesians about life in Russia and its traditions (kekuasaan). (DVET, 18 Juli 2020)

Pada minggu awal pelaksanaan kelas, di beberapa kelas ada mahasiswa yang mendominasi waktu dalam percakapan di kelas (kekuasaan dan ketidaknyamanan). Dominasi waktu oleh mahasiswa menggambarkan adanya kebutuhan pengakuan kekuasaan (kekuasaan dan ketertarikan) yang dimiliki oleh mahasiswa tersebut. Indikator dari kekuasaan yang dimiliki oleh mahasiswa yang mendominasi adalah usia lebih senior, status sosial yang lebih mapan dan gelar pendidikan yang lebih tinggi daripada mahasiswa lain (Ketertarikan kekuasaan). Perbedaan status sosial ini membawa perasaan negatif bagi mahasiswa dengan status sosial yang lebih rendah (ketidaknyamanan). Namun demikian perasaan negatif ini tidak bertahan lama, karena intervensi guru (ketertarikan). Pada minggu kedua dan seterusnya emosi mahasiswa berubah menjadi positif karena mahasiswa bekerjasama dengan baik dan berlaku adil (kenyamanan). (DOET, Zoom, 10 Juni 2020) 
Geografi emosi politik yang terungkap dari data-data di atas menunjukkan bahwa mahasiswa lebih banyak merasa positif daripada merasa negatif. Perasaan positif tersebut diketahui dari parameter ketertarikan, kebahagiaan, kepuasan dan kenyamanan. Perasaan nyaman dimiliki oleh mahasiswa internasional yang mempunyai kekuasaan, misalnya mahasiswa tersebut berpengaruh di kelas, sedangkan perasaan tidak nyaman dirasakan oleh mahasiswa internasional yang tidak memiliki pengaruh atau tidak berkuasa di kelas (Marvell \& Simm, 2018). Data di atas juga menunjukkan bahwa dosen sebagai orang yang memiliki kekuasaan melakukan intervensi untuk menciptakan kenyamanan mahasiswa di kelas. Kekuasaan simbolik juga tampak tersembunyi di balik bahasa yang diungkapkan mahasiswa "Indonesia memiliki hubungan diplomatik baik dengan Rusia". Kalimat yang diucapkan oleh mahasiswa yang seorang diplomat ini, secara tersirat menunjukkan bahwa mahasiswa tersebut memiliki kekuasaan simbolik. Tuturan mahasiswa tersebut menunjukkan bahwa secara tidak langsung dia ingin menunjukkan dirinya berbeda dengan mahasiswa lain. Geografi emosi politik yang dialami mahasiswa internasional di atas menegaskan adanya kekuasaan simbolik di balik tuturan bahasa seseorang (Bourdieu, 1991).

\section{KESIMPULAN}

Penelitian ini menjelaskan studi kasus geografi emosi 25 mahasiswa internasional dari 12 negara dalam belajar bahasa Indonesia bagi Penutur Asing (BIPA) secara daring selama masa COVID-19. Dalam proses pembelajaran BIPA daring pada masa COVID-19 tersebut, mahasiswa internasional mengalami berbagai pergulatan perasaan pada geografi emosi fisik, moral, sosiokultural, profesional dan politik. Berdasarkan parameter yang digunakan, yaitu inclination dan disinclination; happiness dan unhappiness; satisfaction dan dissatisfaction serta security dan insecurity, diperoleh informasi bahwa mahasiswa internasional mengalami berbagai perasaan positif dan negatif dalam belajar BIPA secara daring. Perasaan positif mahasiswa terungkap dalam katakata seperti antusias, bagus, bahagia, baik hati, berdedikasi, berpengalaman, berpengetahuan luas, beruntung, enak, jelas, logis, luar biasa, menarik, nyaman dan sangat puas serta sangat senang. Perasaan negatif tergambar dalam kata cerewet, khawatir, sedih, terkejut, tidak dihormati, tidak nyaman dan tidak suka. Berdasarkan frekuensi hadirnya pengalaman geografi emosi yang dirasakan, mahasiswa lebih banyak dan lebih sering mengalami perasaan positif daripada perasaan negatif. Dari berbagai pergulatan perasaan yang dialami oleh mahasiswa internasional, dapat disimpulkan bahwa secara umum mahasiswa internasional mengalami perasaan geografi emosi positif dan mereka menjaga perasaan tersebut dalam belajar BIPA secara daring pada masa pandemi COVID-19. Berdasarkan temuan penelitian ini, disarankan kepada mahasiswa internasional untuk memiliki perasaan positif dan menjaga perasaan positif dalam menjalani pembelajaran BIPA secara daring. 


\section{Deklarasi Penulis [Disclosure Statement]}

Para penulis menyatakan bahwa tidak ada konflik kepentingan dalam hal riset, kepengarangan dan publikasi artikel ini [The authors declared no potential conflicts of interest with respect to the research, authorship, and/or publication of this article].

\section{Pernyataan Kontribusi Penulis [Authors' Contribution Statements]}

Gatut Susanto: Mengonsep gagasan (utama), merancang metode penelitian (penguat), mengumpulkan data (utama), melakukan kodifikasi data (utama), menganalisis data (utama), menulis draf awal (utama) dan mengedit bahasa (utama) serta merevisi artikel (setara) [conceptualizing ideas (lead), designing research method (supporting), collecting data (lead), coding data (lead), analizing data (lead), writing draft (lead), editing the language (lead), and revising article (equal)]; Suparmi: Mengonsep gagasan (penguat), merancang metode penelitian (utama), menganalisis data (penguat), menulis draf awal (penguat), menulis abstrak berbahasa Indonesia dan Inggris (utama), mengumpulkan dan menelaah referensi (utama), menyelaraskan penulisan referensi (setara), mengedit bahasa (setara) serta merevisi artikel (setara) [conceptualizing ideas (supporting), designing research method (lead), analizing data (supporting), writing draft (supporting), writing abstract in Indonesian and English (lead), collecting and reviewing references (lead), editing references (equal), proofreading the language (equal), and revising the article (equal)]; Endah Yulia Rahayu: Menginisiasi awal menulis artikel (utama), mengoreksi abstrak berbahasa Inggris (penguat), merancang metode penelitian (setara), mengumpulkan dan menelaah referensi (setara), menyelaraskan penulisan referensi (setara) dan mengedit bahasa (setara) serta merevisi artikel (setara) [initiating writing article (lead), proofreading the English abstract (supporting), designing research method (supporting), collecting and reviewing references (equal), editing references (equal), editing the language (equal), and revising the article (equal)].

\section{DAFTAR REFERENSI}

ACTFL Proficiency Guidelines. (2012). American council on the teaching of foreign languages. Diakses tanggal 10 Agustus 2020, www.actfl.org/resources/actfl-proficiency-guidelines-2012.

Anderson, K., \& Smith, S. J. (2001). Emotional geographies. Transactions of the Institute of British Geographers, 26(1), 7-10. DOI: 10.1111/14755661.00002

Barbalet, J. M. (1999). William James' theory of emotions: Filling in the picture. Journal for the Theory of Social Behaviour, 29(3), 251-266. DOI: 10.1111/1468-5914.00101

Bondi, L. (2016). Emotional geographies. New York: Routledge.

Bourdieu, P. (1991). Language and symbolic power. Cambrige, MA: Harvard University Press.

Chick, R. C., Clifton, G. T., Peace, K. M., Propper, B. W., Hale, D. F., Alseidi, A. A., \& Vreeland, T. J. (2020). Using technology to maintain the education of residents during the COVID-19 pandemic. Journal of Surgical Education, 77(4), 729-732. DOI: 10.1016/j.jsurg.2020.03.018 
Choudhury, S., \& Pattnaik, S. (2020). Emerging themes in e-learning: A review from the stakeholders' perspective. Computers \& Education, 144. Terbit pertama online (hlm. 1-20). DOI: 10.1016/j.compedu.2019.103657

Corbera, E., Anguelovski, I., Honey-Rosés, J., \& Ruiz-Mallén, I. (2020). Academia in the time of COVID-19: Towards an ethics of care. Planning Theory \& Practice, 21(2), 191-199. DOI: 10.1080/14649357.2020.1757891

Council of Europe. Council for cultural co-operation. Education committee. Modern languages division. (2001). Common European framework of reference for languages: Learning, teaching, assessment. Cambridge, MA: Cambridge University Press.

Forbes-Mewett, H., \& Sawyer, A. M. (2016). International students and mental health. Journal of International Students, 6(3), 661-677.

Geoghegan, H. (2013). Emotional geographies of enthusiasm: Belonging to the telecommunications heritage group. Area, 45(1), 40-46. DOI: 10.1111/j.1475-4762.2012.01128.x

Hargreaves, A. (2000). Mixed emotions: Teachers' perceptions of their interactions with students. Teaching and Teacher Education, 16(8), 811-826. DOI: 10.1016/S0742-051X(00)00028-7

Hargreaves, A. (2001). Emotional geographies of teaching. Teachers College Record, 103(6), 1056-1080. DOI: 10.1111/0161-4681.00142

Hargreaves, A. (2005). Educational change takes ages: Life, career and generational factors in teachers' emotional responses to educational change. Teaching and Teacher Education, 21(8), 967-983. DOI: 10.1016/j.tate.2005.06.007

Hill, J., Healey, R. L., West, H., \& Déry, C. (2019). Pedagogic partnership in higher education: Encountering emotion in learning and enhancing student wellbeing. Journal of Geography in Higher Education. Terbit pertama online (hlm. 1-19). DOI: 10.1080/03098265.2019.1661366

Little, D. (2006). The common European framework of reference for languages: Content, purpose, origin, reception and impact. Language Teaching, 39(3), 167-190.

Liu, Y. (2016). The emotional geographies of language teaching. Teacher Development, 20(4), 482-497. DOI: 10.1080/13664530.2016.1161660

Manegre, M., \& Sabiri, K. A. (2020). Online language learning using virtual classrooms: An analysis of teacher perceptions. Computer Assisted Language Learning. Terbit pertama online (hlm. 1-16). DOI: 10.1080/09588221.2020.1770290

Martin, J. R., \& White, P. R. R. (2005). The language of evaluation: Appraisal in English. New York: Palgrave Macmillan.

Marvell, A., \& Simm, D. (2018). Emotional geographies experienced during international fieldwork: An evaluation of teaching and learning strategies for reflective assessment. Journal of Geography in Higher Education. Terbit pertama online (hlm. 1-16). DOI: 10.1080/03098265.2018.1460806

Moorhouse, B. L. (2020). Adaptations to a face-to-face initial teacher education course 'forced' online due to the COVID-19 pandemic. Journal of Education for Teaching. Terbit pertama online (hlm. 1-3). DOI: 10.1080/02607476.2020.1755205 
Morgan, H. (2020). Best practices for implementing remote learning during a pandemic. The Clearing House: A Journal of Educational Strategies, 93(3), 135-141. DOI: 10.1080/00098655.2020.1751480

Murphy, M. P. A. (2020). COVID-19 and emergency e-learning: Consequences of the securitization of higher education for post-pandemic pedagogy. Contemporary Security Policy, 41(3), 492-505. DOI: 10.1080/13523260.2020.1761749

OECD. (2012). Education at a glance 2012: Highlights. Paris: OECD Publishing. DOI: 10.1787/eag_highlights-2012-en

Ramirez, A. G. (1995). Creating contexts for second language acquisition: Theory and methods. New York: Longman.

Sidhu, R., \& Ishikawa, M. (2020). Destined for Asia: Hospitality and emotions in international student mobilities. Compare: A Journal of Comparative and International Education. Terbit pertama online (hlm. 1-19). DOI: 10.1080/03057925.2020.1771544

Volet, S., \& Wosnitza, M. (2004). Social affordances and students' engagement in cross-national online learning: An exploratory study. Journal of Research in International Education, 3(1), 5-29.

Widodo, H. P. (2014). Metodological considerations in interview data transcription. International Journal of Innovation in English Language Teaching and Research, 3(1), 101-107.

\section{BIOGRAFI SINGKAT PENULIS [NOTES ON CONTRIBUTORS]}

Gatut Susanto (penulis korespondensi) adalah dosen senior di Jurusan Pendidikan Bahasa Indonesia dan Direktur BIPA di Universitas Negeri Malang, Indonesia. Dia telah mengajar dan mengelola BIPA di Indonesia, Amerika Serikat dan Thailand. Minat penelitian penulis adalah BIPA, sastra, budaya, linguistik, sosiolinguistik dan pragmatik. Email: gatut.susanto.fs@um.ac.id

Gatut Susanto (corresponding author) is a senior lecturer in the Department of the Indonesian Language and director of BIPA at Universitas Negeri Malang, Indonesia. He has taught and managed BIPA in Indonesia, the USA, and Thailand. His research interests focus on BIPA, literature, culture, linguistics, sociolinguistics, and pragmatics. Email: gatut.susanto.fs@um.ac.id

Suparmi adalah dosen bahasa Inggris dan BIPA di Universitas Islam Negeri Maulana Malik Ibrahim Malang, Indonesia. Penelitian utamanya adalah mengajar bahasa Inggris untuk tujuan khusus, integrasi teknologi dalam pengajaran dan pembelajaran bahasa dan BIPA. Email: suparmi@uin-malang.ac.id

Suparmi is an English and BIPA Lecturer at Universitas Islam Negeri Maulana Malik Ibrahim Malang, Indonesia. Her research interests are in teaching English for Specific Purposes, technology-enabled language learning and teaching, and BIPA. Email: suparmi@uin-malang.ac.id 
Endah Yulia Rahayu adalah mahasiswa doktor di Universitas Negeri Malang, Indonesia dan berprofesi sebagai dosen bahasa Inggris di Universitas PGRI Adi Buana, Surabaya, Indonesia. Minat riset penulis di bidang penilaian bahasa, pengajaran bahasa Inggris sebagai bahasa asing dan multikulturalisme. Email: endahyr@unipasby.ac.id

Endah Yulia Rahayu is a doctoral student at Universitas Negeri Malang, Indonesia and has been teaching English at Universitas PGRI Adi Buana, Surabaya, Indonesia. Her research interests lie in language assessment, teaching English as a foreign language (TEFL), and multiculturalism. Email: endahyr@unipasby.ac.id 